\title{
Aйси \\ ПЯТЫЙ ФОРТЕПИАННЫЙ КОНЦЕРТ \\ С. ПРОКОФЬЕВА: КОМПОЗИЦИОННЫЕ И ИСПОЛНИТЕЛЬСКИЕ ИННОВАЦИИ
}

Статья посвящена рассмотрению композиционных и исполнительских инноваций в фортепианном творчестве С. Прокофьева на примере Пятого фортепианного кониерта. Рассматривается феномен «нового фортепиано» в контексте фортепианного инструментализма, техники и технологии композиции. Выявляются аспекты переосмысления романтической трактовки рояля в пользу естественно-ударного.

Ключевые слова: фортепианный концерт, инструментализм, ударная природа фортепиано, исполнительский стиль.

С. Прокофьев - один из ярчайших композиторов-пианистов XX века, смело «взрывавший» каноны как композиторского, так и пианистического мастерства своего времени, но сумевший породить собственную стройную систему выразительных средств в обеих указанных сферах музыкального искусства. Пять фортепианных концертов Прокофьева (созданные в начале и середине его творческого пути - 1912-1932 гг.) ярко отражают наиболее узнаваемые, ключевые и для композиторского творчества, черты артистической индивидуальности автора. Отмежевавшись самым решительным образом от романтической традиции концертного жанра, Прокофьев создал его новый тип - в аспекте фортепианного инструментализма, техники и технологии композиции. Все пять фортепианных концертов «поместились» всего лишь в 20 лет жизни Прокофьева (после 1932 года фортепианных композитор не писал, не считая начатого в 1952-м и незаконченного двойного концерта с предполагаемым посвящением С. Рихтеру и А. Ведерникову). Первый концерт (1911-1912) - самый компактный, небольшой, прозванный «футбольным» за выраженную четкость ритмики и ударность фортепианного звучания. Второй (1912-1913) - «любимый» у самого композитора-исполнителя, отнесенный В. Каратыгиным к «наиболее значительным созданиям новейшей отечественной музыки» и восхитивший Б. Асафьева своей «искренностью, непосредственностью, новизной выражения и насыщенностью содержания» [цит. по 3]. Оба сразу разделили публику и критику на восторженных поклонников и возмущенных оппонентов, 
но не оставили равнодушных. Третий концерт, начатый Прокофьевым в 1913 году, получил завершение только к 1921-му, - по мнению многих исследователей, одно из лучших сочинений Прокофьева, в котором «лирический дух органично соединен с динамизмом развития» [3], пользуется, пожалуй, наибольшей популярностью вплоть до сегодняшнего дня (в том числе и у китайских пианистов). Четвертый концерт для левой руки, написанный для пианиста П. Витгенштейна, потерявшего правую руку на войне, завершен в 1931 году, но исполнен уже после ухода Прокофьева. И, наконец, Пятый - пятичастный - концерт (1932) также был оценен и понят не сразу, его признание было во многом связано с выступлением Святослава Рихтера уже в 1941 году. Именно этот последний, «с опозданием» принятый и понятый, привлек наше исследовательское внимание возможностью проанализировать в творчестве гениального композитора-пианиста органичное совмещение фортепианно-концертной революционности средств, «оптимистического фортепиано» с классической (неоклассической) ясностью мышления (и духа) - как «тяготения к определенности, ясности, порядку» (С. Тараканов [7, с. 420]), но в формате своего времени, своей эпохи.

«Картина мира» каждого из пяти фортепианных концертов С. Прокофьева является уникальным воплощением концертного жанра, фортепианной и исполнительской поэтики. Ее амплитуда простирается от моторной токкатности, блистательной техники гамм и пассажей до утонченно хрупкой, оцененной слушателями и критикой только со временем, лирики; от резких гротескных контрастов, изобилия остроумных выдумок до жизнеутверждающего солнечного пафоса, естественного, подлинного оптимизма; от принципиально ясной, кристальной чистоты формы и фактуры (как носителей приемов высокой музыки эпохи клавира) до неожиданных и нестандартных музыкально-драматургических поворотов.

«Стальной скок» прокофьевской ритмики наполнен той энергией духа, которая созвучна его собственному мироощущению эпохи. А. Шнитке говорит об особом, «естественном», «не идеологически внушенном, но самом что ни на есть подлинном» оптимизме Прокофьева, солидаризованном с «эпохой и ее атрибутами - скорыми поездами, автомобилями, самолетами, телеграфом, радио и так далее, - что давала отрезвляюще-экстатическую, раз и навсегда достигнутую, точнейшую организацию времени, отразившуюся и в житейских привычках Прокофьева» [8]. Возможно, поэтому жесточайшие 
в истории человечества испытания, трагические события XX века долго воспринимались современниками (в том числе Прокофьевым) как случайность, отсутствие «справедливой» логики, трагическое недоразумение. Соответственно оптимизм, ставший исходным жизненным пунктом, принципом мышления в начале столетия (совпавший хронологически со становлением личностных и музыкантских качеств Прокофьева), сохранился и в дальнейшем, пусть и с неизбежной корректировкой. Указанная философия (идеология) творческого и жизненного (даже житейского) мышления, оправданная надеждами начала XX века на «долгожданную надежность исторического маршрута», на скорое падение всех препятствий, естественно, сказалась на звуковых реалиях прокофьевского фортепиано, на композиционных, фактурных и других принципах музыки, на своеобразном «уходе» от некрасивых, «вредных» реалий - к неоклассицистской ясности и чистоте формы и фактуры, но и к действенной энергии и ритмической напористости. Отсюда, как отмечает А. Шнитке, «холодная, спортивная жизненная установка на наиполезнейшее, равно как и одухотвореннейшее, в судьбах молодых людей (начала XX в. - A.), Прокофьева в том числе» [8].

Указанная А. Шнитке «точнейшая организация времени» выражается в аркадьевских законах взаимодействия «звучащей» и «незвучащей», неакустической основ. Ведь каждая эпоха обладает «своей специфической формой как собственно «незвучащего» пульсационного континуума (времени-энергии), так и формой их взаимодействия. Кажется вполне вероятным, что подобное предположение будет верным и в отношении индивидуальной манеры композитора» [2, с. 183]. Тезис о том, что существующие основные законы бытия, единые и существенные для всех его составляющих, проявляются и в авторском энергетическом континууме, творчество Прокофьева подтверждает с живой и убедительной силой. Та «сфера волевого развертывания... пульсирующая среда, внутри которой разворачивают свою энергию элементы звуковой ткани... энергетическое поле, составляющее как бы скрытую жизненную сущность произведения», в музыке Прокофьева оборачиваются преобладанием в ней различных форм моторики, определенностью и важностью метро-ритмических формул, четкостью (исполнительского и композиторского) артикулирования, как в целом, так и в деталях, квадратностью построений, расчлененностью формы и завершенностью ее отдельных частей. У Прокофьева подчинение себе «незвучащего» временного потока 
по-баховски (недаром же задуманный Прокофьевым в последний год жизни двойной фортепианный концерт имел своим идейным прототипом двойные концерты И. С. Баха) предполагает исполнительское внедрение в него «организующего пульса», той живой оси, на которой держится вся ткань произведения с соответствующим энергетично направленным естественно-ударным (для фортепиано) типом туше, способом звукоизвлечения. Эта непрерывность пульса (в звучащих тонах и в паузах) помогает исполнителю (и композитору) овладеть необратимой стихией «живого времени». А «музыка Прокофьева даже в самых отвлеченных ее моментах всегда связана с реальными процессами, с действием или даже просто с движением» (Э. Денисов [4]). Недаром же в Пятом фортепианном концерте углубились и расширились связи с балетным искусством. Так, уже в первой части (Allegro con brio) Прокофьев сразу погружает слушателя в атмосферу радостно-энергичного танца со сценически-карнавальной (балетной) сменой масок, танцев-пантомим. Здесь очень важно взаимодействие пульсации с артикулируемой мотивной тканью.

Пятичастный Пятый концерт необычен и с точки зрения формы. Отметим, что в истории фортепианного концерта пятичастный цикл все же встречался. Так, в 1906 году Ф. Бузони написал Концерт для фортепиано с оркестром в пяти частях общей продолжительностью около семидесяти минут, с хоровым финалом; пять частей имеют «Движения» для фортепиано с оркестром Стравинского (1959), фортепианный концерт Б. Чайковского (1971) и Д. Лигети (1988), Тройной концерт Е. Подгайца для фортепиано, скрипки, виолончели (1988). По сравнению с ними Пятый концерт для фортепиано Прокофьева (1932) весьма компактен, это «некий квазиконцерт, продолжительностью около 25 минут» [5, с. 79].

Таким образом, уникальная прокофьевская «формула времениэнергии» (М. Аркадьев) в микро- и макроструктурах, общие композиционные принципы Прокофьева «основаны на прояснении логики внутреннего строения, а не на усложнении и варьировании ее. Кажущаяся элементарность прокофьевских форм ни в коей мере не связана с облегченностью формообразования или же с реставрационно-неоклассическими устремлениями - скорее эта «элементарность» происходит от высоко развитого конструктивного мышления, помогающего композитору найти в каждом индивидуальном случае максимально ясное решение данной композиционной проблемы» [4]. Сам Прокофьев так пишет об этом в «Автобиографии»: «Если выделить в 
сторону одноручный Четвертый, то со времени сочинения Третьего прошло более десяти лет, создались новые концепции того, как обращаться с этой формой, пришли в голову кое-какие приемы (пассаж через всю клавиатуру, во время которого левая рука перегоняет правую; аккорды у рояля и оркестра, перебивающие друг друга, и т. д.), наконец, в записной книжке накопилась пачка бодрых мажорных тем. Концерт я вначале не хотел делать трудным и даже предполагал назвать его «Музыкой для фортепиано с оркестром» [цит. по 3]. Однако «легкой» музыки у Прокофьева (как и в целом ряде опусов этого периода) не получилось, концерт оказался сложным во всех отношениях и почти десять лет пролежал «на полке». Прокофьев сам пытается выяснить причины такого усложнения, самокритично полагая, что во всем виновата его извечная боязнь «проторенных дорог», часто разрушавшая искреннее стремление композитора к ясности и простоте (вспомним его житейскую организованность времени). Впрочем, после исполнения концерта в 1941 году «ясным» по природе С. Рихтером ситуация вокруг концерта несколько изменилась.

Известно, что сам Прокофьев не был доволен «пианизмом» концерта. По собственным словам композитора, по окончании оркестровки он «засел за зубрежку его фортепианной партии, все время жалуясь на ее «трудноватость», тем более первоначально, как уже указывалось, он задумывал «вещь легкую и эффектную» [там же]. Концерт действительно отличается некоторой «отвлеченной моторностью» и «жестким утрированием архаичных приемов фортепианного письма Доменико Скарлатти (а он писал для клавесина!)» (Дельсон [3]). Но знаменитая (уже сегодня) прокофьевская лирика, прогрессирующая с точки зрения композиторского стиля - вдохновенная, мягкая и светлая, «оттеснившая» жесткую моторность, в четвертой части; жанрово-выразительная, сказочно-чарующая в пятой части необыкновенно возвышает весь концерт. В целом фортепианная партия написана мастерски виртуозно, эффектно и своеобразно. Здесь нет традиционных для XIX века каденций, нет выявленной сонатности в развертывании формы, но точно выражены здоровый, подлинный оптимизм, жизнерадостный искрящийся юмор и поэтичнейшие страницы лирики, наметившей путь психологического усложнения (разрастание основного тематического ядра, полифонизация ткани в среднем разделе четвертой части; длительное проведение своеобразного полиладового комплекса, эффекты затормаживания «сценического действия» в пятой части). 
В этом произведении можно обнаружить также противоречивые стремления Прокофьева к монументально-симфонической и к камерно-инструментальной сферам, по-разному проявляющиеся на творческом пути композитора. Подобная «монтажность» проявляется, прежде всего, в формообразовании. Все пять частей концерта относительно малы, но тяготеют к целостности всей формы. В предисловии к авторскому переложению концерта для двух фортепиано В. Блок высказал предположение об «известной степени ... рондообразности» композиционной формы концерта, в которой «первая, третья и пятая части построены на одинаковом или сходном материале и являются своего рода рефренами рондо, а вторая и четвертая части - его эпизодами. Эта особенность сочинения заставляет вспомнить «Испанское каприччио» Римского-Корсакова, где также налицо рондообразность цикла (с существенными изменениями рефрена в последней части сочинения)» [цит. по 3]. Одновременно в структуре концертного цикла намечаются черты дивертисмента (об этом пишет А. Алексеев [1, с. 84]) «с отчетливо выраженными элементами пластического начала, пантомимы» [там же]. Характерно, что при этом Прокофьев не порывает с традициями концертного жанра, но по-своему творчески их преобразует. Так, несмотря на значительную трансформацию последнего, в нем сохранено традиционное сочетание быстрых (сонатное аллегро или рондо-соната) и медленных лирических частей. Вместо обычного для дивертисментно-сюитного цикла ослабления связей между частями ощушается симфоническая целостность формы с использованием структурного принципа симметрии. Отметим здесь, что в каждом из своих концертов Прокофьев находил оригинальные приемы трактовки концертного жанра и композиторских приемов. Возможно, хореографическая дивертисментность Пятого концерта специально оттенена сквозной линией тематического развития, что подтверждается наличием необычной третьей части, в которой мы слышим основные темы первой части (Allegro) в новом жанровом - токкатном «одеянии», а также подчеркивается необычностью финала - своеобразной арки к первой части, продолжающей и постепенно гасящей токкатное начало в театрализованном затормаживании «действа». Упоминавшиеся выше в связи с исполнительским подчинением «незвучащего» временного потока некоторые черты «бахианства» Прокофьева в Пятом концерте обнаруживаются также в стремлении к возрождению баховских принципов соотношения партий рояля и оркестра: отсутствие форте- 
пианных каденций и развернутых оркестровых тутти; наличие своеобразного симфонического ансамбля оркестра и рояля при большей тематической нагрузке последнего.

Эффектная, но полностью соответствующая содержанию произведения партия рояля также сочетает «приемы сонатинности в предшествовавших Пятому концерту произведениях (Две сонатины, ор. 54)» и «громоздкие приемы монументального пианизма, не всегда гармонично сочетающегося с чертами камерности» [3] (напомним, что Прокофьев первоначально хотел назвать Пятый концерт «Музыкой для фортепиано с оркестром»). Партия рояля отличается свежестью фортепианных фактурных приемов: «пассаж через всю клавиатуру, во время которого левая рука перегоняет правую; аккорды у рояля и оркестра, перебивающие друг друга и т. д.» [6, с. 189]; глиссандо по белым клавишам в правой - и быстрое позиционное движение по черным (первая часть) или более сложная фигурация (вторая часть) в левой; быстрые пассажи, построенные на попеременном исполнении разными руками пятипальцевых и других фигур или звуков; использование первого пальца для взятия двух клавиш одновременно; игра акцентов в басу на черных клавишах col pugno («горстью» пальцев); обильное и разнообразное использование звучностей верхнего регистра. Многочисленны, разнообразны, часто необычны - любимые, а также отменно получавшиеся у самого Прокофьева скачки в фортепианной партии. Пожалуй, в Пятом концерте оформлена наиболее красочная, нарядная, сложная для исполнения и эффектная фактура из всех фортепианных сочинений композитора (в дальнейшем он пошел в этом плане по пути отказа от пышной декоративности пианистических средств выразительности в пользу психологизированной лаконичности инструментального высказывания).

Первая часть (Allegro con brio) представляет форму рондо-сонаты. Экспозиция довольно краткая: активная, гротескно заостренная ГП (где рояль явно «ведет»); лирическое dolce у струнных в СП; радостно-энергичная, блестящая, родственная главной ПП (с яркими фанфарами трубы); маршеобразная ЗП (духовые и триольные пассажи рояля - после повторения ГП в той же тональности). Видимый контраст между главными темами (танцевально-эксцентричными) «компенсируется» их совместным контрастом к фоновым темаминтермедиям (бально-танцевальным). Разработка с чередованием двух главных тем также лаконична (с упоминаемыми ремарками «col 
pugno в партии рояля). Центральный эпизод - Meno mosso - сам трехчастный, демонстрирует новую тему с собственным варьированием и нести черты мечтательной танцевальности. После репризы ГП используется оригинальный прием своеобразного соперничества «наскакивающих» друг на друга мощных аккордов фортепиано и оркестра (con precisione). Таким образом, вся часть не лишена определенной мозаичности; одновременно описанными композиционными приемами создается цельная структура концертно-симфонического типа, в которой А. Алексеев видит квазихореографическое действие [1, с. 81].

Bторая часть - Moderato ben accentuato - вариации на две попеременно разрабатываемые темы (двойные вариации с чертами трехчастности с синтетической кодой). Угадывается причудливый прокофьевский марш-шествие - метрически упругий, ироничносаркастичный, скерцозный (глиссандо, скачки, вспыхивающие пассажи, «стеклянное» стаккато, резкие акценты у рояля; пиццикато струнных и резкость медных - подчеркнутая сухость высказываний; сопоставление одноименного мажора и минора), но вмещающий также и определенную лирическую манерность старинных танцев.

Tретья часть - Allegro con fuоco - весьма необычна (токката, подчеркивающая ведущую роль действенного начала в прокофьевском творчестве и в данном цикле). Новые формы такой действенности (эмоционально нагнетаемые вплоть до финала концерта) представляют (иногда прямо, как в конце части) музыкальный материал ГП и ПП. Здесь целый фейерверк фортепианных звучностей, свежих приемов игры - гроздья аккордов, пассажи из двойных нот, скачки по всей клавиатуре, использование прокофьевских стеклянных тембров. Не менее колюч и одновременно прозрачен оркестр. Возвращение главных тем (в оркестре) как бы временно сдерживает токкатную устремленность, не исчерпывая ее. Тем логичнее воспринимается предельно контрастная четвертая часть.

«Волшебно-лирическая» четвертая часть - Larghetto - наглядная демонстрация эволюции композиторского стиля в сторону знаменитой сегодня гуманистической прокофьевской лирики. Покачивающийся ритм нежно-пластичной колыбельной, утонченно засурдиненные струнные способствуют постепенному распеванию основного тематического ядра на широком дыхании (авторские ремарки «нежно», «спокойно», «приглушенно», «очень тихо», «связно»). Бесспорно, это лирическая кульминация в токкатном «теле» 
цикла. В среднем разделе (Piu mosso) музыка драматизируется, приобретает черты широкой пафосно окрашенной декламационности, мелодия полифонизируется подголосками (многие исследователи тут видят прямую связь с русской песенностью). Реприза возвращает слушателя к нежным материям, растворяющимся в тишине после взлетающего пассажа рояля.

Пятая часть - Vivo - вдохновенная токката («отложенная» предыдущей лирической) в форме рондо-сонаты. Особенно яркими кажутся две темы: легкая, подвижно-острая (си-бемоль минор) и радостная, жанрово-пасторальная. К концу разработки музыка приобретает характерный для Прокофьева завораживающе-волшебный формат (цифра 100 - эпизод «сказочного очарования» с характерной полиладовостью несколько напоминает композиционные приемы «сказочных» эпизодов Глинки) и появляется скерцозно-воздушная, жизнерадостная кода с новой темой в характере марша-шествия (цифра 104).

Таким образом, Пятый фортепианный концерт отмечен целым рядом новационных приемов композиции и фортепианного инструментализма. Он не только завершает определенный (зарубежный) этап творчества композитора, но во многом предвосхищает следующий. Так, В. Блок отмечает: «Темы финала своим образным содержанием и в жанровом отношении, несомненно, близки к массовым сценам прокофьевских балетов («Народный танец» в «Ромео и Джульетте», сцена ярмарки в «Сказе о каменном цветке»)» [цит. по 3]. Не умещаясь в роль «продолжателя традиций» (пусть и значительно, индивидуально преображенных), Прокофьев, несомненно - смелый и дерзкий родоначальник новых звуковых реалий (фортепиано и жанра). Он смело экспериментирует с циклом концерта (исключение, пожалуй - «классический» Третий), привнося заряд оптимистически-действенной энергии, ритмической напористости. Исполнительское внедрение «организующего пульса» в ткань музыки соотносится с соответствующим энергетично направленным естественно-ударным (для фортепиано) типом туше, способами звукоизвлечения. Преодоление романтической трактовки рояля проявляется по нескольким линиям: отказ от чувственно-певучего («вокального») звучания в пользу указанного естественно-ударного (сухое, жесткое, «стекляное») с частым использованием крайних регистров; актуализация специфической акцентуации, non legato, артикулирования; минимализация фактуры, линеарность, «неперегруженность». Все 
это наследует традиции раннеклассического и классицистского клавирного искусства, а в русской традиции - Мусоргского. Однако, несмотря на преобладание указанных антиромантических традиций, в фортепианном стиле Прокофьева очень важны и черты романтического пианизма, что особенно справедливо в отношении его знаменитой гуманистической кантилены. Как многие композиторы-пианисты (Шопен, Лист, Скрябин, Рахманинов), Прокофьев создает «новый рояль» в расчете «на себя», на свой блестящий пианистический аппарат и новое слышание ноосферы своей эпохи. Разрыв с романтической тенденцией выявляется и в своеобразии противостояния сольной партии и оркестра как единого монолитного организма в пользу идеи игры-состязания, что приводит к обогащению симфонизированного концертного жанра принципами театральной и монтажно-кинематографической (уже XX века) драматургии. Указанные процессы, с одной стороны, выступая формальным показателем продолжения традиций, с другой - ярко демонстрируют новаторскую роль Прокофьева, внесшего значительный вклад в становление концертного жанра и фортепианного звучания («нового фортепиано») в современную эпоху.

\section{СПИСОК ЛИТЕРАТУРЫ}

1. Алексеев А. Советская фортепианная музыка (1917-1945) / А. Д. Алексеев. - М. : Музыка, 1974. - 248 с., 8 л. ил., нот.

2. Аркадьев М. Фундаментальные проблемы музыкального ритма и «незвучащее». Время, метр, нотный текст, артикуляция / М. Аркадьев. - М. : LAP LAMBERT Academic Publishing, 2012. - 408 c.

3. Дельсон В. Фортепианное творчество и пианизм Прокофьева / В. Ю. Дельсон. - М. : Сов. композитор, 1973. - 286 с.

4. Симонянц Е. Токкатно-ударная трактовка рояля в фортепианных концертах отечественных композиторов второй половины XX - начала XXI столетий : дис. ... канд. искусствоведения : 17.00.02 / Елена Михайловна Симонянц. - М., 2014. - 198 с.

5. Прокофьев С. С. Материалы. Документы. Воспоминания / сост., ред., примеч., вступит, статья С. И. Шлифштейна. - Изд. 2-е, доп. - М. : Гос. муз. изд-во, 1961. $-707 \mathrm{c.}$

6. Тараканов М. Стиль симфоний Прокофьева : исследование / М. Е. Тараканов. - М. : Музыка,1968. - 432 с.

7. Шнитке А. Слово о Прокофьеве // А. Г. Шнитке. Беседы, выступления, статьи : беседы, интервью, вступит, статья, каталог сочинений, список статей и интервью, иллюстрации, 1994 г. / сост. и авт. вступ. ст. А. В. Ивашкин. М. : РИК «Культура», 1994. - С. 210-214. 
Aїсі. П'ятий фортепіанний концерт С. Прокоф'єва: композиційні та виконавські інновації. Стаття присвячена розгляду композиційних та виконавських інновацій у фортепіанній творчості С. Прокоф'єва на прикладі п'ятого фортепіанного концерту. Розглядається феномен «нового фортепіано» в контексті фортепіанного інструменталізму, техніки й технології композиції. Виявляються аспекти переосмислення романтичного трактування рояля на користь природно-ударного.

Ключові слова: фортепіанний концерт, інструменталізм, ударна природа фортепіано, виконавський стиль.

Aysi. Fifth Piano Concerto by Prokofiev: composite and performing innovation. The article considers the composition and performing innovations in the piano works of Prokofiev on the example of the fifth piano concerto. The phenomenon of the «new piano» in the context of piano instrumentalism, technique and technology composition. I dentifies aspects of rethinking romantic piano interpretation in favor of the natural impact.

Keywords: Piano Concerto, instrumentalism, impact nature piano, performing style.

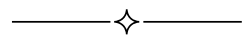

УДК $78.03 / 782.1$

\section{Бай Цюань}

\section{СЕМАНТИЧЕСКИЕ УРОВНИ ОПЕРНОЙ КОМПОЗИЦИИ: ВОКАЛЬНО-ИСПОЛНИТЕЛЬСКИЙ АСПЕКТ ОПЕРОВЕДЕНИЯ}

В статье представлены перспективные музыковедческие подходы $\kappa$ изучению содержания и формы оперного произведения. Обособляется феномен оперного мелоса, определяется особый характер оперного мелодийного тематизма, разрабатываются ключевые категории вокальноисполнительского анализа оперного текста. Выделяются три основных семантических уровня оперной композиции и способы их характеристики.

Ключевые слова: оперная композиция, семантические уровни, оперный герой, оперный мелос, мелодийная тема.

Осваивая репертуар европейской оперы, в частности, произведения русских композиторов классического периода истории русской музыки, китайские оперные исполнители обнаруживают необходимость создания такого музыковедческого подхода к оперной композиции, который позволяет выявлять ее смыслообразующие стороны,

(c) Бай Цюань, 2014 